\title{
THE RECONSTRUCTION OF PALEOVEGETATION AND PALEOCLIMATE IN THE LATE PLIOCENE OF WEST YUNNAN, CHINA
}

\author{
XIANG-YU KOU ${ }^{1,2,3,6}$, DAVID K. FERGUSON ${ }^{4}$, JING-XIAN XU ${ }^{5}$, YU-FEI WANG ${ }^{1}$ \\ and CHENG-SEN LI ${ }^{1,2,5, *}$ \\ ${ }^{1}$ Laboratory of Systematic and Evolutionary Botany, Institute of Botany, Chinese Academy of \\ Sciences, Beijing, 100093, P.R. China \\ ${ }^{2}$ The State Key Laboratory of Loess and Quaternary Geology, Institute of Earth Environment, \\ Chinese Academy of Sciences, Xi' an, 710075, P.R. China \\ ${ }^{3}$ College of Resources Science and Technology, Beijing Normal University, 100875, P.R. China \\ E-mail: kouxiangyu@hotmail.com \\ ${ }^{4}$ Department of Paleontology, University of Vienna, Althanstraße 14, A-1090 Vienna, Austria \\ ${ }^{5}$ Beijing Museum of Natural History, Beijing, 100050, P.R. China \\ (*Author for correspondence: E-mail:Lics@ibcas.ac.cn) \\ ${ }^{6}$ Graduate School of the Chinese Academy of Sciences, Beijing, 100049, P.R. China
}

\begin{abstract}
The Eryuan palynoflora from the Late Pliocene of western Yunnan, China is described in this paper, and is compared with two contemporary palynofloras from Yangyi and Longling. The palynological data of the three locations are analyzed to reconstruct the climatic parameters of these areas at that time by using the Coexistence Approach. The Late Pliocene climatic parameters of Eryuan are estimated, i.e., the mean annual temperature ranged from 13.3 to $18.6^{\circ} \mathrm{C}$, the mean temperature of the warmest month from 24.6 to $27.5^{\circ} \mathrm{C}$, the mean temperature of the coldest month from 1.9 to $12.1^{\circ} \mathrm{C}$, the difference in temperatures of coldest and warmest month from 14.2 to $16.6^{\circ} \mathrm{C}$, the mean annual precipitation from 619.9 to $1484.3 \mathrm{~mm}$, the mean maximum monthly precipitation from 143.8 to $245.6 \mathrm{~mm}$, and the mean minimum monthly precipitation from 12.7 to $16.4 \mathrm{~mm}$. Both paleovegetation and paleoclimate of the three localities are compared with the modern data at each location. The present study suggests a MAT decrease accompanied by a doubling of the MAP in the Longling area between the Late Pliocene and the present. This seems to be related to the uplift of Gaoligong Mountain in Longling which is now part of the eastern portion (Western Yunnan) of the Tibetan Plateau.
\end{abstract}

Yunnan is situated on the Southeastern edge of the Qinghai-Xizang (Tibet) Plateau. Geographically, it represents only 4\% of China, but it contains 13278 (45.9\%) species of vascular plant (WGYV, 1987). Complex vertical zonation and a variety of vegetation types are characteristic of the modern environment in western Yunnan. In the Cenozoic, the uplift of the Tibetan Plateau strongly influenced the area, forming a very complicated geographic environment (BGMRYP, 1990; Zhang et al., 1997). Former research regards the Neogene as a key stage of terrestrial environmental evolution in Yunnan (Xu et al., 2004).

Eryuan is situated on the western slope of the Diancang Mountain in northwest Yunnan. The Liantie coal-bearing deposit of this area (Figure 1) was assigned to the Sanying Formation of Late Pliocene age, based on a lithostratigraphic 


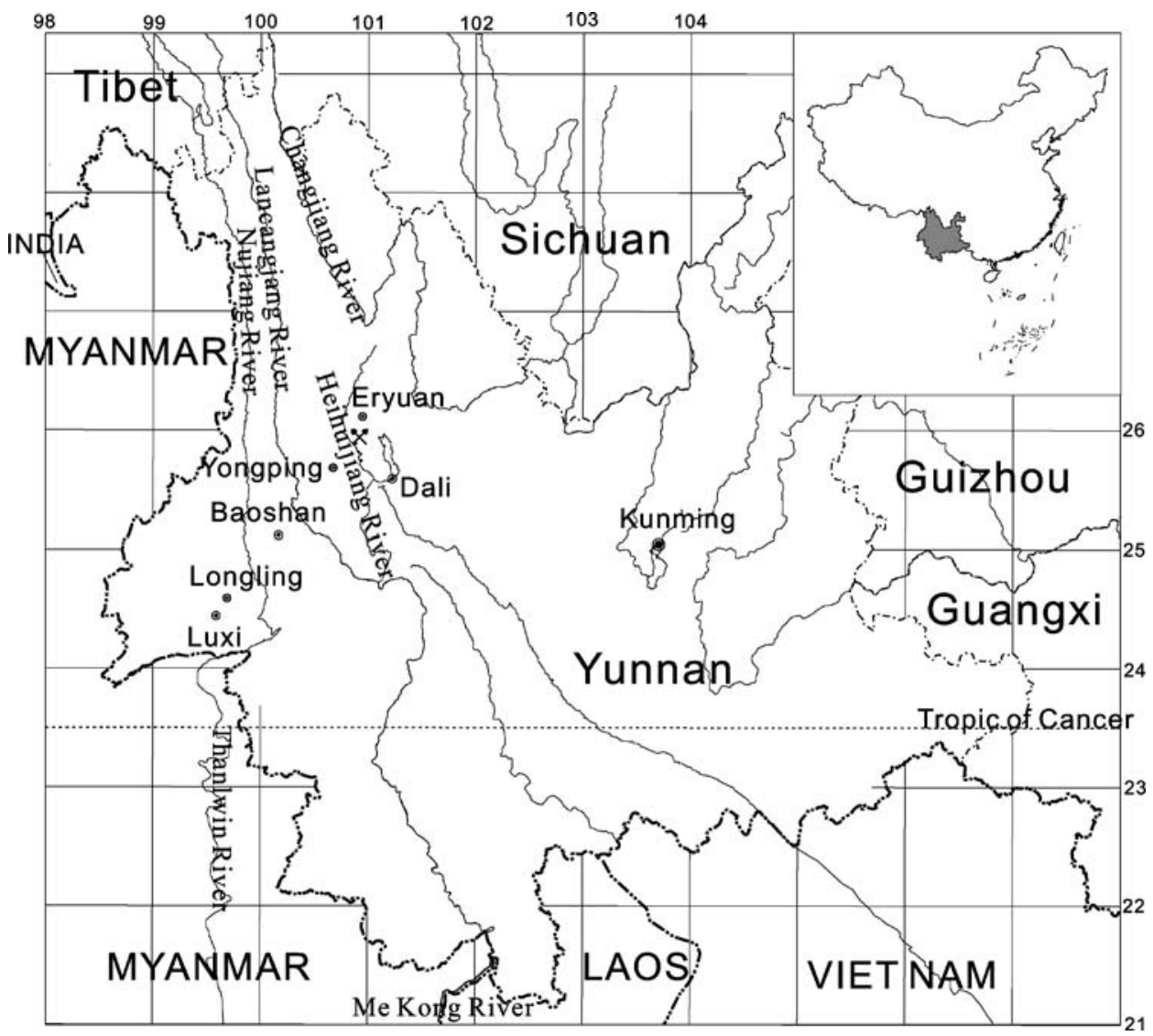

Figure 1. The regional map to show the position of Eryuan, Basoshan (Yangyi), and Longling.

and biostratigraphic comparison with the middle-late Pliocene flora of Mt. Shisha Pangma in the Himalayas (Hsü et al., 1973; Tao and Kong, 1973; BGMRYP, 1990; BGMRYP, 1996; Ge and Li, 1999). Tao and Kong initiated work on the Upper Pliocene Flora of the Sanying Formation (Tao and Kong, 1973).

In western Yunnan two other late Pliocene palynofloras, i.e. Yangyi (Xu, 2002; $\mathrm{Xu}$ et al., 2003) and Longling (Xu, 2002; Xu et al., 2003; Xu et al., 2004) have been recorded recently. In the present investigation, seven dimensional climatic parameters of the three locations are estimated using the Coexistence Approach (Mosbrugger and Utescher, 1997; Xu et al., 2000), and paleovegetation, paleoclimate are compared with the modern data.

\section{Materials and Methods}

The Liantie coal mine $\left(26^{\circ} 00.20^{\prime} \mathrm{N}, 99^{\circ} 49.06^{\prime} \mathrm{E}, 2280 \mathrm{~m}\right.$ a.s.l. $)$ lies in Liantie Village, Eryuan county, Yunnan in China (Figure 1). The profile exposed at Liantie 
Coal Mine, is about $90 \mathrm{~m}$ thick (Figure 2). The studied section was overlain by Quaternary conglomeratic sediment. The underlying bed is grey limestone (Triassic) (BGMRYP, 1990; BGMRYP, 1996). 56 palynological samples from the profile were collected and analyzed in the present investigation (Figure 2).

The samples were treated by the traditional method of heavy liquid separation (Density $=1.8 \mathrm{~g} / \mathrm{ml}$ ) (Moore et al., 1991; $\mathrm{Li}$ and $\mathrm{Du}, 1999$ ). No pollen grains or spores were found in 11 samples, fewer than 200 grains (3-161) were found in 22 samples, while more than 200 grains (206-613) were found in the other 14 samples. All the samples with fewer than 200 grains are based on counting at least 5 slides under the microscope.

The pollen grains and spores were identified by comparison with the modern palynological literature (IBCAS, 1976; IBCAS and SCIBCAS, 1982; Wang et al., 1995).

The reconstruction of paleoclimate in Eryuan is attempted following the Coexistence Approach (CoA) (Mosbrugger and Utescher, 1997; Xu et al., 2000). The method is based on the coexistence interval of the climatic tolerance of the taxa in a plant assemblage. The climatic tolerances of the seed plants were obtained from the climatic records within their modern distribution area (Wu and Ding, 1999).

As an example, the procedure for obtaining the climatic tolerance of Quercus is shown in Figure 3. All points in the distribution of Quercus (oak) in China are shown in Figure 3, and seven-dimensional climatic parameters from each point were collected. From the climatic parameter data, the maximum and minimum of each parameter of every single dimension were established. In the four chosen points of Quercus distribution in Figure 3, the meteorological stations provided the minimum of Mean Annual Temperature (MAT) being $-4.9^{\circ} \mathrm{C}$ in Mohe, being $24.7^{\circ} \mathrm{C}$ in Dongfang, the minimum of Mean Annual Precipitation (MAP) being $213.1 \mathrm{~mm}$ in Alxa zuoqi, the maximum of MAP being $1869.6 \mathrm{~mm}$ in Taipei. Therefore the MAT tolerance of Quercus is from -4.9 to $24.7^{\circ} \mathrm{C}$, and the MAP tolerance from 213.1 to $1869.6 \mathrm{~mm}$ (Figure 7). In the same way, parameters of the other five dimensions viz., the Mean Temperature of the Warmest Month (MWMT); the Mean Temperature of the Coldest Month (MCMT), the Difference of Temperatures of coldest and warmest month (DT), the Mean Maximum monthly Precipitation (MMaP), the Mean Minimum monthly Precipitation (MMiP) are established.

The modern climatic data recorded by the meteorological stations of China are extracted from publications of the Information Department of Beijing Meteorological Center (IDBMC) (1983a, b, 1984a, b, c, d). Sometimes the distribution area of a genus extends beyond China. For example, in the genus Quercus, we checked the recent research papers which mentioned the genus with the meteorological record in Belgium (Maes et al., 1999), Spain (Infante et al., 1999), Italy (Nardini et al., 2000), Nepal (Vetaas, 1999), Mexico (De Buen and Ornelas, 2002) and USA (Hutchinson et al., 1999) (Table I); These demonstrate that all the records fall within the range of tolerance of Quercus. 


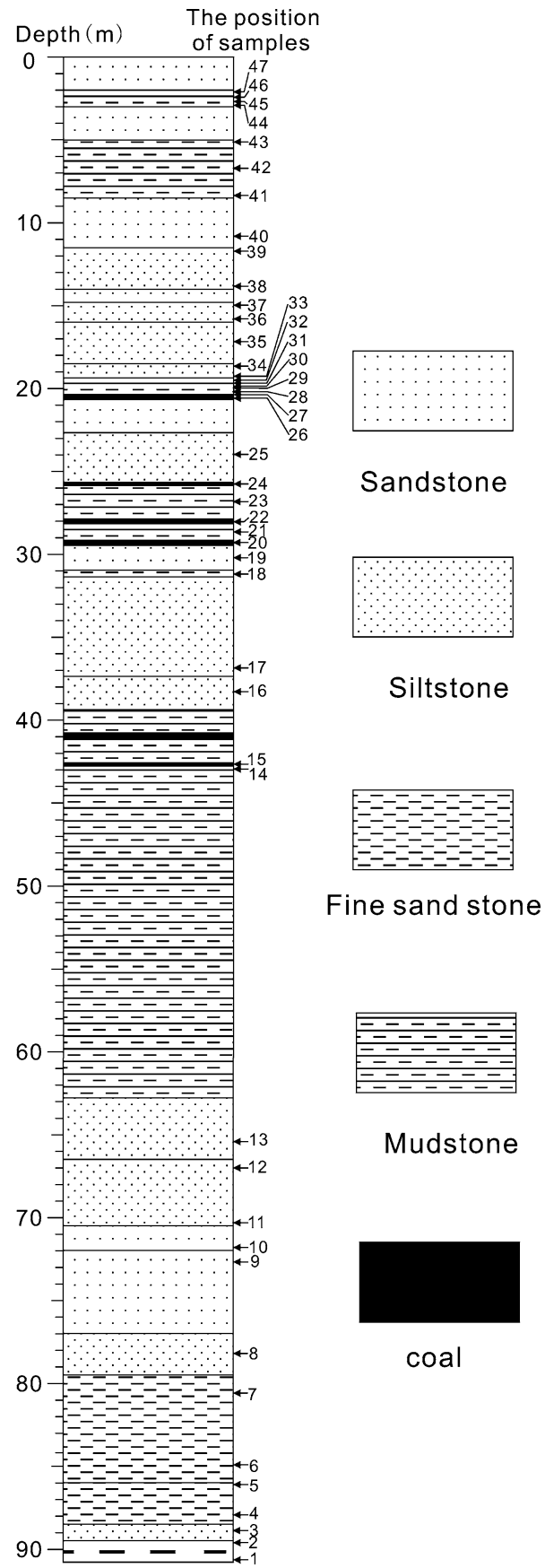

Figure 2. Measured of stratigraphical section of liantie coal mine and the positions of the samples. 


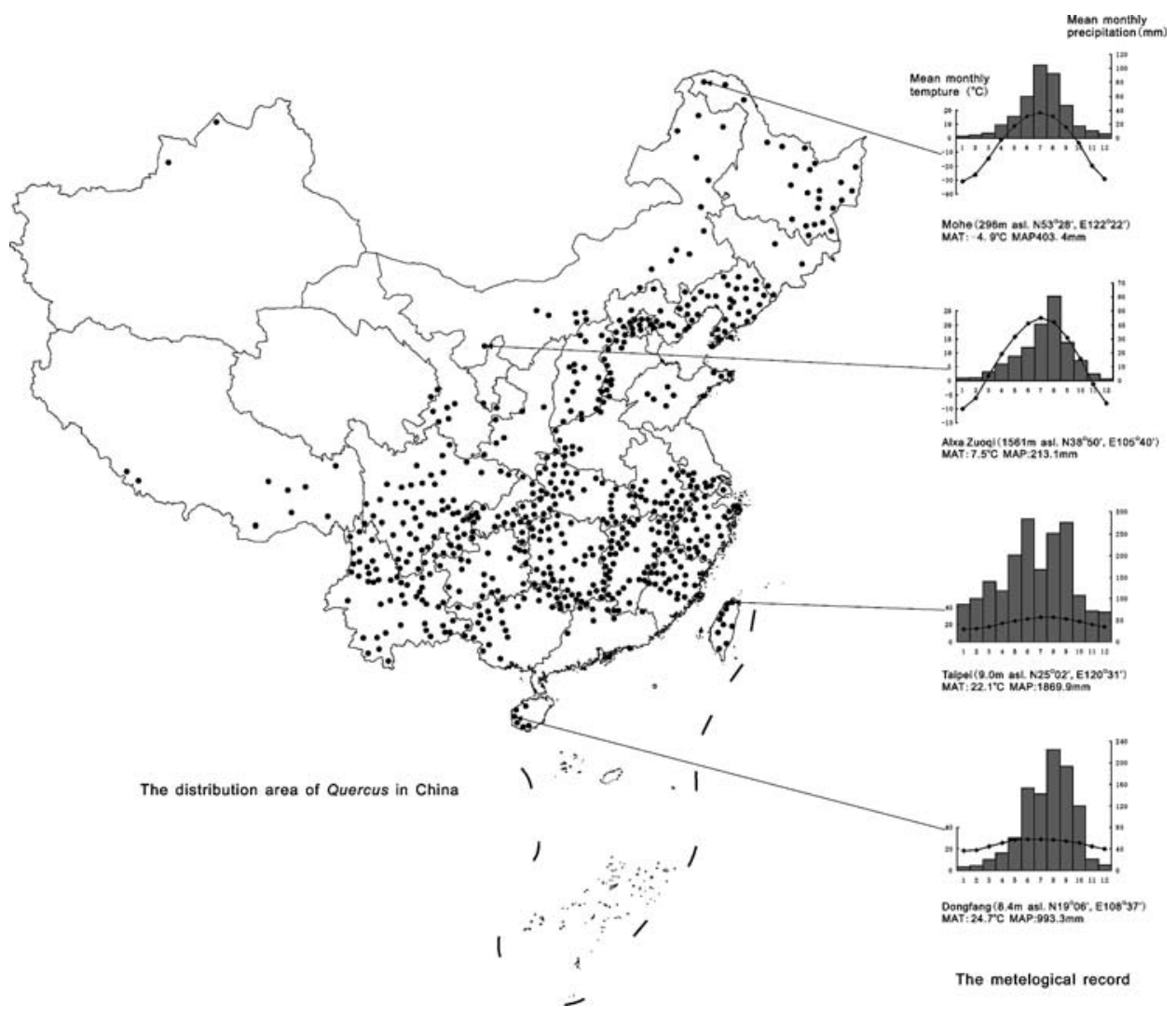

Figure 3. An example (Quercus) to show the procedure for obtaining the climatic tolarence.

\section{Result}

The Eryuan palynoflora consists of 58 palynomorphs belonging to 49 families. Most are angiosperms (75.9\%), but gymnosperms (8.6\%) and pteridophytes (15.5\%) are also represented (Table II, Figures 4 and 5). Angiosperm pollen represents 44 types assigned to 38 families. The gymnosperms include 4 genera of Pinaceae and 1 type of Taxodiaceae. The pteridophytes include 9 types belonging to 9 families. Based on the appearance of each palynomorph and its main changes in the total pollen diagram (Figure 6), 3 palynological zones could be recognized:

Zone 1 (90.65-66.85 $\mathrm{m}$ in depth): Conifer tree taxa range from 27.2 to $87.5 \%$ of the pollen sum, thus dominating the pollen assemblage. The montane conifer $P i$ nus (pine), ranging from 18 to $86 \%$, is particularly well-represented, while Abies (fir), Picea (spruce), Tsuga (hemlock), and Taxodiaceae were also present. Many broadleaved tree taxa (20 types, mainly Quercus (oak) and Alnus (alder)), are present, with a total percentage of 5 to $67 \%$. Herbaceous taxa (mainly Artemisia, 
TABLE I

The MAT and MAP in the distribution area of Quercus beyond China form the recent study about the genus

\begin{tabular}{lllll}
\hline Place & Location & Altitude (m a.s.l.) & MAT $\left({ }^{\circ} \mathrm{C}\right)$ & MAP (mm) \\
\hline Southeast Belgium $^{\mathrm{a}}$ & - & 320 to 335 & 7.7 & 1000 \\
Orense, Spain $^{\mathrm{b}}$ & $42^{\circ} 21^{\prime} \mathrm{N}, 7^{\circ} 51^{\prime} \mathrm{W}$ & 130 & 14 & 818 \\
Barcelona, Spain $^{\mathrm{b}}$ & $41^{\circ} 24^{\prime} \mathrm{N}, 2^{\circ} 09^{\prime} \mathrm{E}$ & 90 & 16 & 595 \\
Trieste Venezia Giulia, $^{\circ}$ & $45^{\circ} 46^{\prime} \mathrm{N}, 13^{\circ} 35^{\prime} \mathrm{E}$ & 20 & 12.5 to $15.5^{*}$ & 1150 \\
Italy $^{\mathrm{c}}$ & & & & \\
Messina, Sicily, Italy $^{\mathrm{c}}$ & $38^{\circ} 23^{\prime} \mathrm{N}, 15^{\circ} 56^{\prime} \mathrm{E}$ & 500 & 16.5 to $18.5^{*}$ & 365 \\
Okladunga, Nepal $^{\mathrm{d}}$ & $27^{\circ} 19^{\prime} \mathrm{N}, 86^{\circ} 30^{\prime} \mathrm{E}$ & 1720 & 16.4 & - \\
Tengboche, Nepal $^{\mathrm{d}}$ & $27^{\circ} 50^{\prime} \mathrm{N}, 86^{\circ} 46^{\prime} \mathrm{E}$ & 3857 & 3.9 & - \\
Xalapa, Veracruz, Mexico $^{\mathrm{e}}$ & $19^{\circ} 30^{\prime} \mathrm{N}, 96^{\circ} 57^{\prime} \mathrm{W}$ & 1300 & 18 & 1500 \\
Vinton, Ohio, USA $^{\mathrm{f}}$ & $39^{\circ} 12^{\prime} \mathrm{N}, 82^{\circ} 23^{\prime} \mathrm{W}$ & 208 to 307 & 11.3 & 1024 \\
$\begin{array}{l}\text { The tolerance of } \text { Quercus } \\
\text { from Chinese data }\end{array}$ & - & - & -4.9 to 24.9 & 213.1 to 1869.6 \\
\hline
\end{tabular}

${ }^{*}$ Calculated as the arithmetic mean of MCMT and MWMT.

${ }^{\text {a }}$ Cited from Maes et al. (1999).

${ }^{\mathrm{b}}$ Cited from Infante et al. (1999).

${ }^{\mathrm{c}}$ Cited from Nardini et al. (2000).

${ }^{\mathrm{d}}$ Cited from Vetaas (1999).

${ }^{\mathrm{e}}$ Cited from De Buen and Ornelas (2002).

${ }^{\mathrm{f}}$ Cited from Hutchinson et al. (1999).

Chenopodiaceae) representing 13 types are also present, with a total ranging from $3.4 \%$ to $25 \%$. A few aquatics (Typha (reedmace) and Potamogetonaceae (pondweeds)) are restricted to this zone; the ferns are represented by Polypodiaceae, Gleicheniaceae, Pteridaceae and Lycopodium (clubmoss), normally less than $1 \%$.

Zone 2 (66.85-31.95 $\mathrm{m}$ in depth): Only two types of conifer (Pinus and Tsuga, with a total percentage of 19 to $70.7 \%$ ) are recorded along with a few broadleaved trees (13 types with a total percentage of 11 to 24\%), the main genera being Quercus and Alnus, as well as herbs (6 types) e.g. Artemisia and Chenopodiaceae, totaling 3.6 to $32 \%$; no aquatics were found; of the 4 pteridophyte types, Lycopodium peaked $(46.77 \%)$ at $42.5 \mathrm{~m}$ in depth.

Zone 3 (31.95-0 $\mathrm{m}$ in depth): Conifer tree taxa are represented by three types, i.e. Abies, Pinus, and Tsuga, with a total percentage ranging from $11 \%$ to $72.5 \%$; of the 18 broadleaved tree types (10 to 85.7\%), Quercus and Alnus remain dominant, 12 types of herbs, ranging from 5 to 66.7\%, are dominated by Artemisia and Chenopodiaceae, while 9 types of ferns including Dennstaedtiaceae, Polypodiaceae, Sinopteridaceae, Gleicheniaceae, Pteridaceae, Hymenophyllaceae, Gymnogrammaceae, Lycopodium and Selaginellaceae are recorded; Lycopodium continues to be important, reaching $67.37 \%$ at $24.15 \mathrm{~m}$ depth. 
TABLE II

The list of palynomorphs

\begin{tabular}{ll}
\hline Pteridophyta & \\
Dennstaedtiaceae & Hymenophyllaceae \\
Polypodiaceae & Gymnogrammaceae \\
Sinopteridaceae & Lycopodium \\
Gleicheniaceae & Athyriaceae \\
Pteridaceae & \\
Gymnosperms & \\
Abies & \\
Pinus & Tsuga \\
Picea & Taxodiaceae \\
Angiosperms & \\
Trees and shrubs & \\
Alnus & \\
Betula & \\
Carpinus & Rubiaceae \\
Corylus & Oleaceae \\
Castanea & Palmae \\
Castanopsis & Theaceae \\
Quercus & Myrtaceae \\
Fagus & Herbs \\
Liquidambar & Verbenaceae \\
Ericaceae & Cyperaceae \\
Ilex & Erodium \\
Ulmus & Polygonaceae \\
Juglans & Chenopodiaceae \\
Lythraceae & Convolvulaceae \\
Euphorbiaceae & Gesneriaceae \\
Anacardiaceae & Humulus \\
Araliaceae & Lamiaceae \\
Rabaceae & Cruciferae \\
Tilia & Thalictrum \\
Meliaceae & Gramineae \\
Celastraceae & Compositae \\
\hline & Artemisia \\
\hline & Caryophyllaceae \\
Sapindaceae & \\
& \\
Pidonaceae \\
\hline
\end{tabular}

The three zones are very similar in having same major tree genera Pinus, Quercus, Alnus, and herbaceous taxa Artemisia and Chenopodiaceae. Even though there were some fluctuations in the three zones, the main types remained the same. It shows that a subtropical mixed evergreen coniferous and broad-leaved forest existed in this mountainous area. 

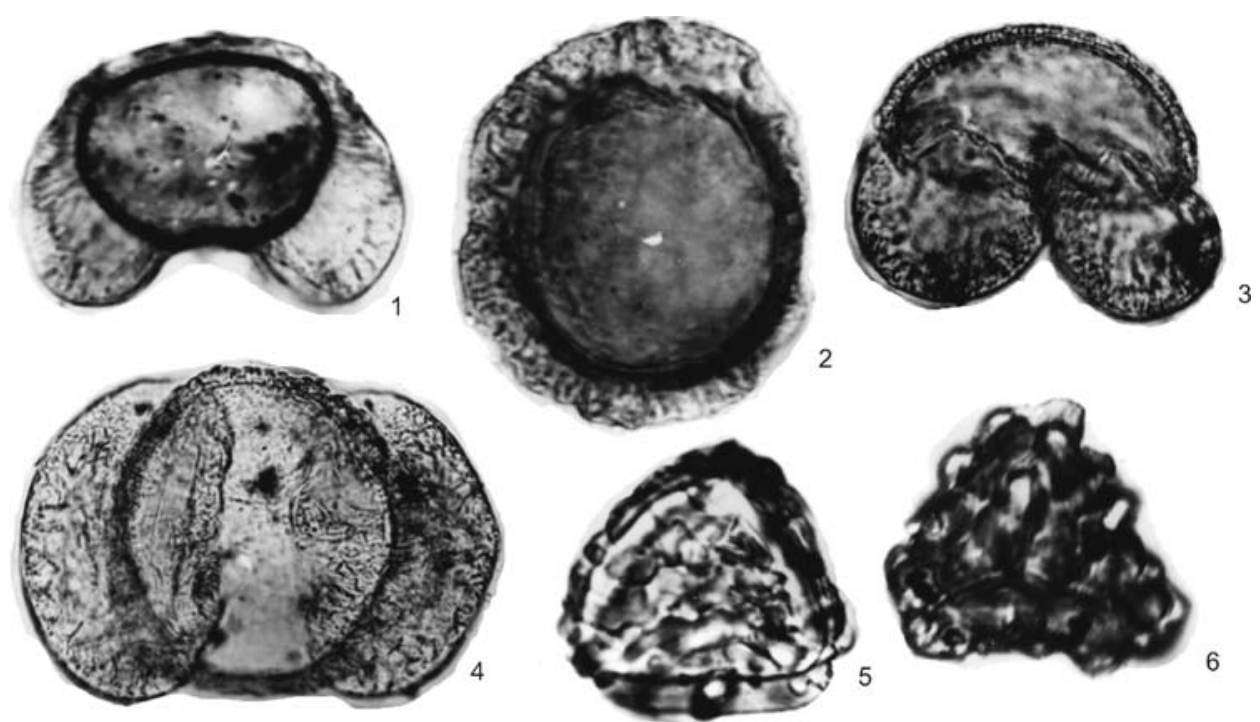

2
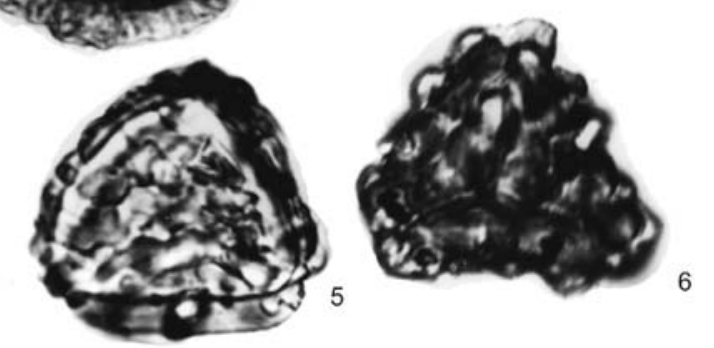
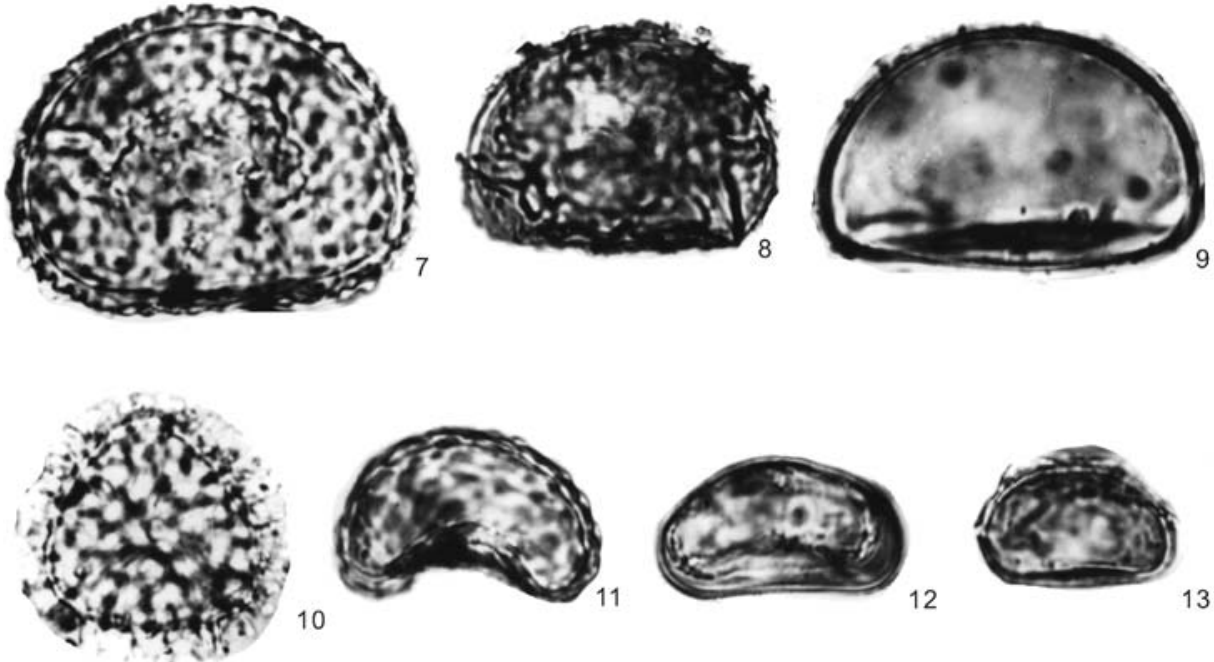

Figure 4. (1). Cedrus Trew (2). Tsuga Carr. (3,4). Pinus L. (5, 6). Pteris Linn. (7, 9, 11). Polypodiaceae $(8,12,13)$. Athyriaceae $(10)$. Lycopodiaceae $(1-4 \times 600,5-13 \times 800)$.

The paleoclimatic intervals in Eryuan (Upper Pliocene) which were obtained using the Coexistence Approach are shown in Figure 7. The mean annual temperature ranged from 13.3 to $18.6^{\circ} \mathrm{C}$, the mean temperature of the warmest month from 24.6 to $27.5^{\circ} \mathrm{C}$, the mean temperature of the coldest month from 1.9 to $12.1^{\circ} \mathrm{C}$, the difference in temperatures of coldest and warmest month from 14.2 to $16.6^{\circ} \mathrm{C}$, the mean annual precipitation from 619.9 to $1484.3 \mathrm{~mm}$, the mean maximum monthly precipitation from 143.8 to $245.6 \mathrm{~mm}$, and the mean minimum monthly precipitation from 12.7 to $16.4 \mathrm{~mm}$ (Table III). 


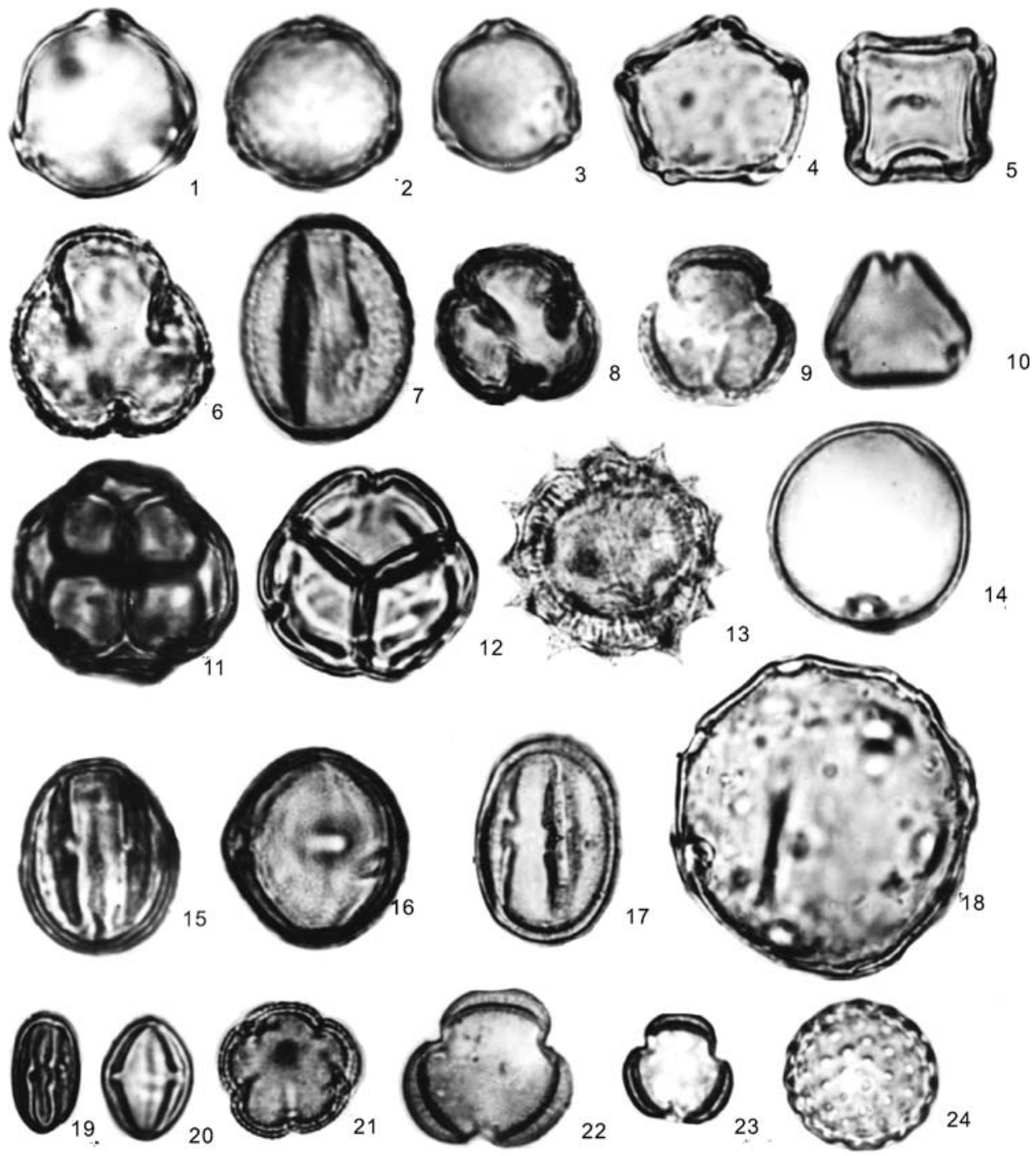

Figure 5. (1). Betula L. (2). Ulmus L. (3). Corylus L. (4, 5). Alnus Mill. (6, 7, 8). Quercus L. (9). Artemisia L. (10). Sapindaceae (11, 12). Ericaceae (13). Compositae (14). Gramineae (15). Leguminosae. (16). Anacardiaceae (17). Polygonaceae (18). Juglans L. (19, 20). Castaneoideae (21). Rubiaceae (22, 23). Artemisia L. (24). Chenopodiaceae (1-24 × 1000).

\section{Discussion}

The Eryuan palynoflora contains much Pinus throughout the sequence, the highest level being almost $86 \%$. Quercus and Alnus were the main angiosperm trees, accompanied by a number of herbs like Artemisia and Chenopodiaceae. Some tropical or subtropical types such as Liquidambar, Euphorbiaceae, Sapindaceae, Palmae 


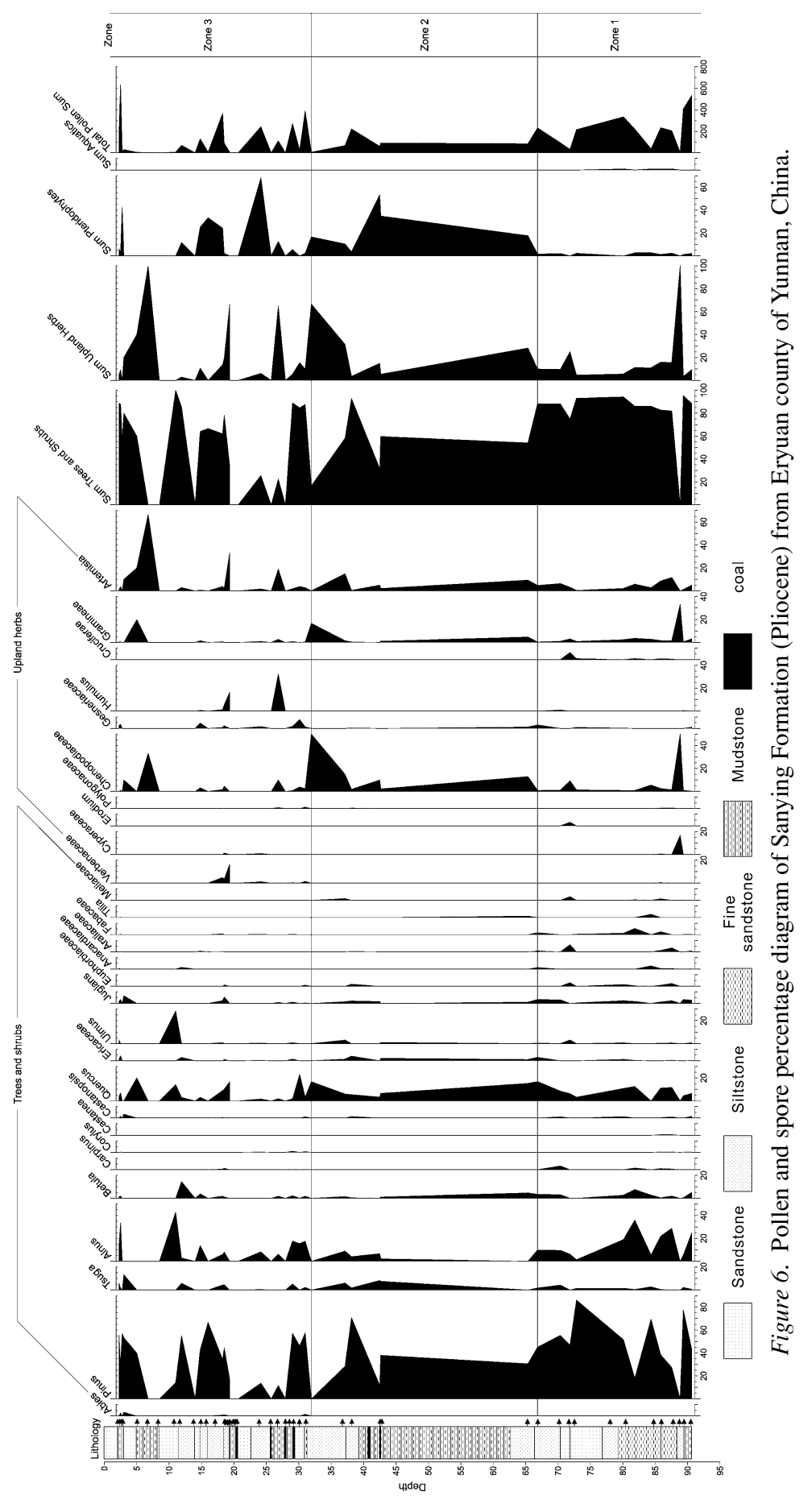




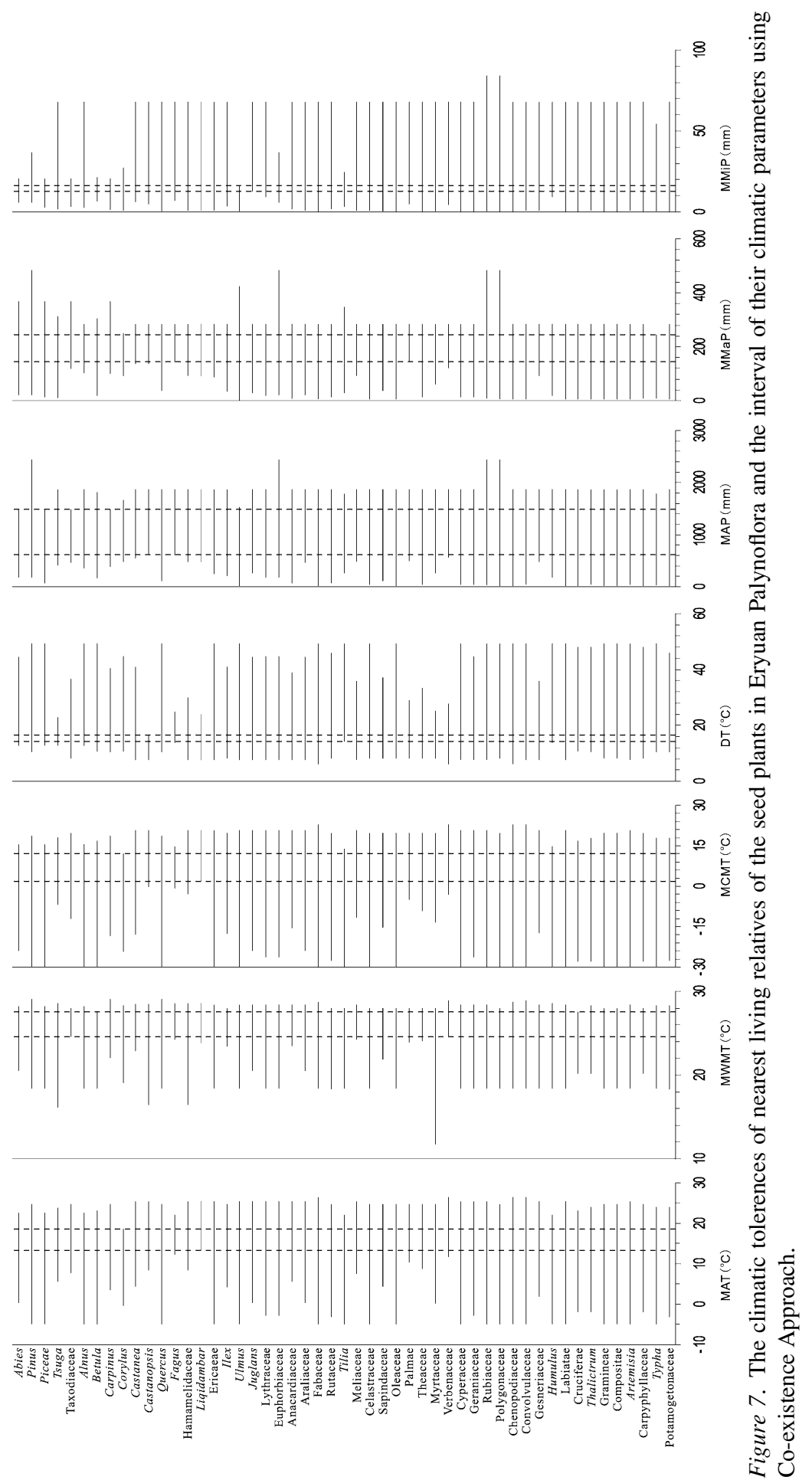


TABLE III

The climate parameters of Pliocene in Eryuan area obtained by the method of Coexistence Approach compared with the modern climate

\begin{tabular}{lll}
\hline Climate parameters & Pliocene & Modern \\
\hline $\operatorname{MAT}\left({ }^{\circ} \mathrm{C}\right)$ & $13.3-18.6^{\circ} \mathrm{C}$ & $13.9^{\circ} \mathrm{C}^{*}$ \\
$\operatorname{MWMT}\left({ }^{\circ} \mathrm{C}\right)$ & $24.6-27.5^{\circ} \mathrm{C}$ & $20^{\circ} \mathrm{C}^{*}$ \\
$\operatorname{MCMT}\left({ }^{\circ} \mathrm{C}\right)$ & $1.9-12.1^{\circ} \mathrm{C}$ & $6.7^{\circ} \mathrm{C}^{*}$ \\
$\operatorname{DT}\left({ }^{\circ} \mathrm{C}\right)$ & $14.2-16.6^{\circ} \mathrm{C}$ & $13.3^{\circ} \mathrm{C}^{*}$ \\
$\operatorname{MAP}(\mathrm{mm})$ & $619.9-1484.3 \mathrm{~mm}$ & $650.2-1456.5 \mathrm{~mm}^{* *}$ \\
$\operatorname{MMaP}(\mathrm{mm})$ & $143.8-245.6 \mathrm{~mm}$ & $229.0 \mathrm{~mm}^{* *}$ \\
$\operatorname{MMiP}(\mathrm{mm})$ & $12.7-16.4 \mathrm{~mm}$ & $12.4 \mathrm{~mm}^{* *}$ \\
\hline
\end{tabular}

Note. ${ }^{*}$ The record of Eryuan Meteorological Station (WCECA, 1996).

** The record of Dali Meteorological Station (No. 56751) (IDBMC, 1984e; Chen, 2001).

also appeared frequently. It suggests that conifers like Tsuga, Picea, Abies lived at higher altitudes; The predominance of Pinus may simply reflect its high pollen production and efficient dispersal. At mid-elevation the forest consisted of Quercus (oak), Alnus (alder), Betula (birch), Tilia (lime), Ulmus (elm) etc., while the lower part included some thermophilic trees such as Liquidambar, Euphorbiaceae, Sapindaceae and Palmae. Herbs such as Artemisia and Chenopodiaceae etc. lived on grassy slopes.

The Yangyi, Longling and Eryuan palynofloras are located in western Yunnan (Figure 8), and are Late Pliocene in age (BGMRYP, 1990; 1996). Like the other two palynofloras, the Eryuan palynoflora contains numerous angiosperms (44 of 58 taxa). However the proportion of angiosperm pollen (43.5\%) is less than that of the gymnosperms $(47.5 \%)$ (Table IV).

Based on a comparison of the three localities with the vertical vegetation belts and modern vegetation (Table IV), most elements of the Eryuan palynoflora would appear to have been derived from the semi-moist evergreen coniferous and broadleaved mixed forest belt at $1600-2500 \mathrm{~m}$, with a small contribution from the coniferous forest above $2900 \mathrm{~m}$. Most elements of the Yangyi palynoflora were derived from the evergreen coniferous and broad-leaved mixed forest of $2700-3000 \mathrm{~m}$, with a minor input from the coniferous forest above $3000 \mathrm{~m}$. Most elements of the Longling palynoflora originated from the modern humid evergreen coniferous and broad-leaved mixed forest at elevations of 1600 to $2500 \mathrm{~m}$, with fewer contributions from evergreen coniferous and broad-leaved mixed forests from 2400 to $2900 \mathrm{~m}$.

The deposits of Sanying Formation (Eryuan), Mangbang Formation (Longling) and Yangyi Formation (Yangyi) in western Yunnan belong to Upper Pliocene (BGMRYP, 1990; BGMRYP, 1996). Using the Coexistence Approach, the paleoclimate of the three localities is quantitively assessed. 


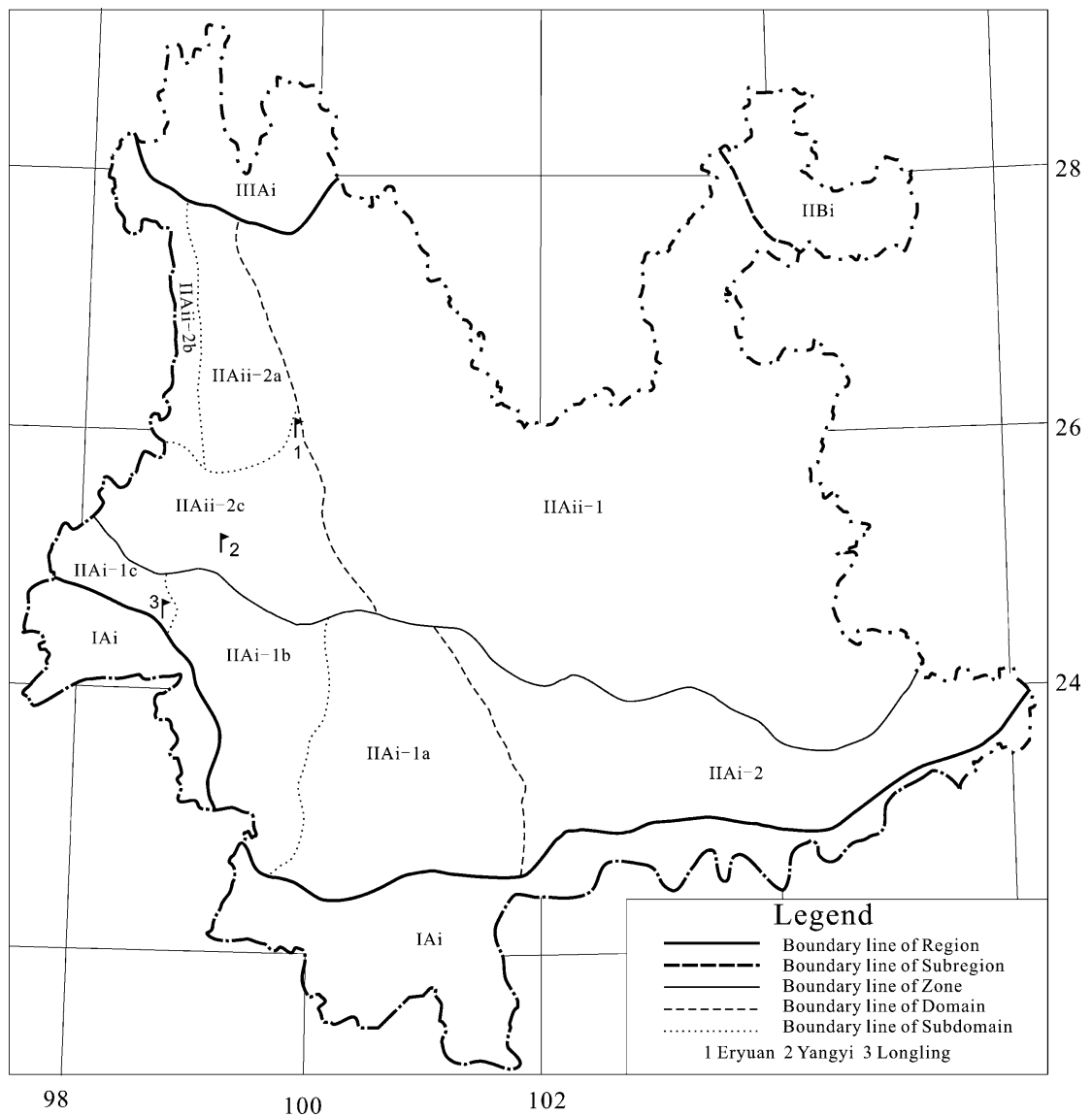

Explanation : (Regionalization of Yunnan vegetation)

(I) Region of tropical monsoon forest, rain forest,

(IA) Subregion of monsoon forest, rain forest of western China,
(IAi) of northern tropical seasonal rain forest and semi-evergreen monsoon forest

(II) Region of subtropical evergreen broad-leaved forest,

leaved forest of western China,

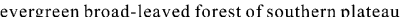

(IIAi-1)Domain of monsoon evergreen broad-leaved forest found in midmontane of southwestern Yunnan,

(IIAi-1a) Subdomain of montane Castanopsis hystrix-C. microcarpa forest and Pinus kesiya var. langbianensis forest,

(IIAi-1b) Subdomain of montane Castanopsis hystrix-C. indica forest and Lithocarpus echinotholus forest,

(IIAi-1c) Subdomain of mid-montane Castanopsis ferox, C. Hystrix-Lithocarpus truncatus forest,

(IIAi-2)Domain of monsoon evergreen broad-leaved forest of southeastern Yunnan,

(IIAii)Zone of subtropical evergreen broad-leaved forest of northern plateau,

(IIAii-1)Domain of semihumid evergreen broad-leaved forest and Pinus yunnanensis forest of central and eastern Yunnan,

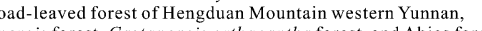

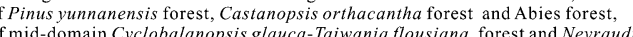

reynaudianagrassland,

Cyclobalanopsis glauca-Taiwania flousiana forest and Neyraudia Subdomain of mid-

(IIB) Region of humid evergreen broad-leaved forest of eastern China,

(IIBi)Zone of mid-subtropical evergreen broad-leaved forest.

(III) Region of alpine vegetation of Qinghai-Tibet Plateau,

(IIIA) Subregion of cold temperate coniferous forest of Southeastern Qinghai-Tibet Plateau,

(IIIAi)Zone of cold temperate coniferous forest and meadow of Southeastern Qinghai -Tibet Plateau, and

Figure 8. The location of Eryuan, Yangyi, Longling, in the vegetation, regionalization map of Yunnan provinces (WGYV, 1987). 


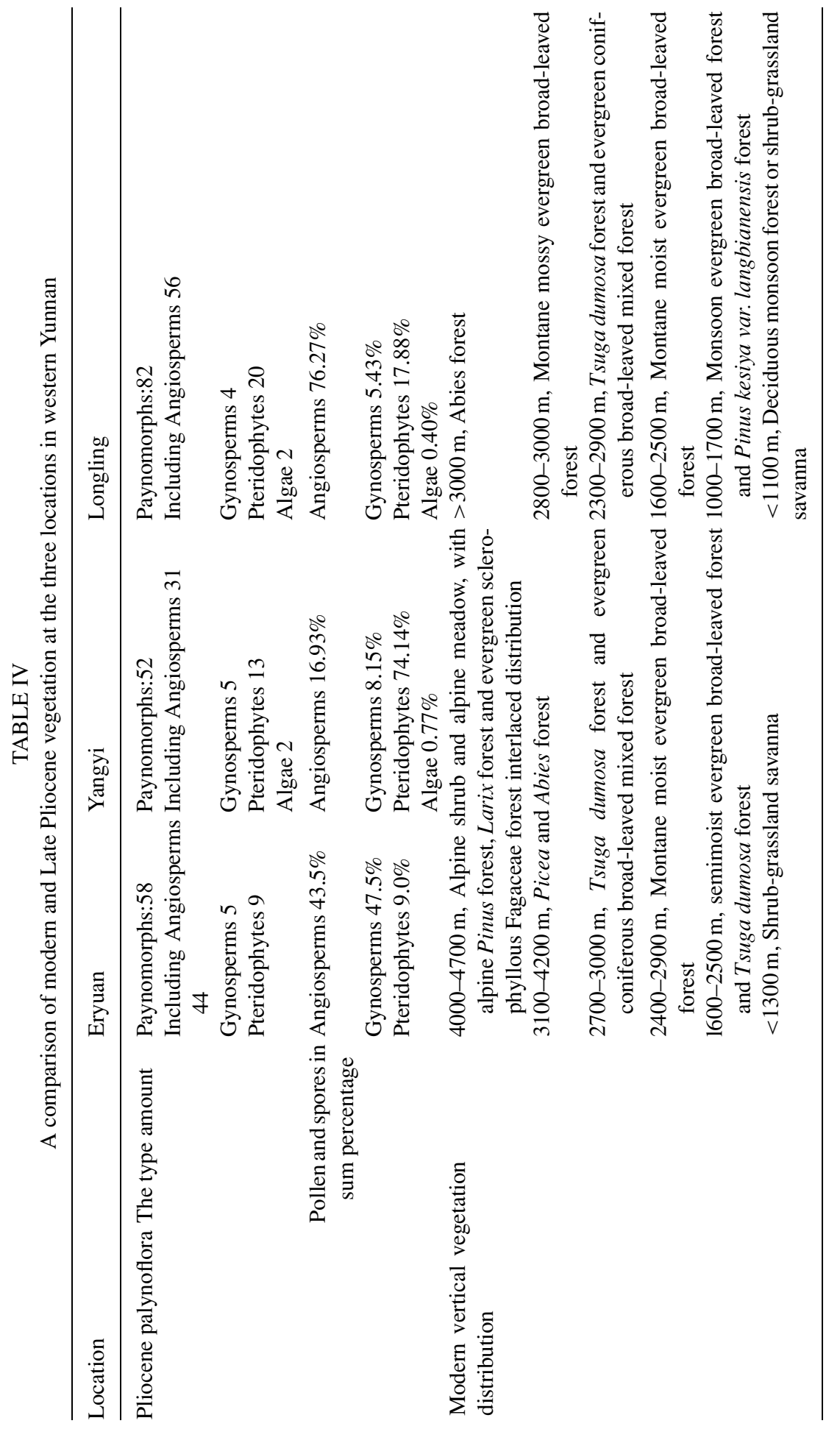


TABLE V

The paleoclimate and modern equivalent of Eryuan, Yangy and Longling

\begin{tabular}{lllll}
\hline Location & Position and altitude & Time & $\begin{array}{l}\text { MAT (mid-value) } \\
\left({ }^{\circ} \mathrm{C}\right)\end{array}$ & $\begin{array}{l}\text { MAP (mid-value) } \\
(\mathrm{mm})\end{array}$ \\
\hline Eryuan & $\left(26^{\circ} 00^{\prime} \mathrm{N} 99^{\circ} 49^{\prime} \mathrm{E}, 2279 \mathrm{~m}\right.$ a.s.l.) & Modern & $13.9^{\mathrm{a}}$ & $1078.9^{\mathrm{a}}$ \\
Yangyi & $\left(24^{\circ} 57^{\prime} \mathrm{N} 99^{\circ} 15^{\prime} \mathrm{E}, 1521 \mathrm{~m}\right.$ a.s.l.) & Modern & $15.5^{\mathrm{b}}$ & $966.4^{\mathrm{b}}$ \\
Longling & $\left(24^{\circ} 41^{\prime} \mathrm{N} 98^{\circ} 50^{\prime} \mathrm{E}, 1802 \mathrm{~m}\right.$ a.s.l.) & Modern & $14.9^{\mathrm{c}}$ & $2122^{\mathrm{c}}$ \\
\hline Eryuan - & Pliocene & $13.3-18.6(15.95)$ & $619.9-1484.3(1052.1)$ \\
Yangyi - & Pliocene & $13.3-20.9(17.1)$ & $797.5-1254.7(1026.1)$ \\
Longling - & Pliocene & $18.6-22.1(20.35)$ & $815.8-1254.7(1035.25)$ \\
\hline
\end{tabular}

${ }^{\mathrm{a}}$ The record of Dali Meteorological Station (No. 56751) (IDBMC, 1984e; Chen, 2001).

${ }^{b}$ The record of Baoshan Meteorological Station (No. 56748) (IDBMC, 1984e; Chen, 2001).

'The record of Longling Meteorological Station (WGYV, 1987).

All of the late Pliocene and modern climatic data from the three localities are shown in Table V. The MATs in late Pliocene, with means given in brackets, display a similar trend trend from high temperatures to lower ones $\left(20.35\right.$ to 17.1 to $\left.15.95^{\circ} \mathrm{C}\right)$ with increasing latitude from Longling through Yangyi to Eryuan. On the other hand, the MAPs remained fairly constant from Longling through Yangyi to Eryuan (with means of 1035.25, 1026.1, and $1052.1 \mathrm{~mm}$ respectively) in late Pliocene times.

Based on the modern meteorological records, Yangyi and Eryuan demonstrate that the MATs change with an increase in latitude $\left(15.5\right.$ to $\left.13.9^{\circ} \mathrm{C}\right)$, while the MAP changed only marginally (966.4 to $1078.9 \mathrm{~mm}$ ). However, the record from Longling displays a marked difference, with the MAT dropping to $14.9^{\circ} \mathrm{C}$, while the MAP doubled to $2122 \mathrm{~mm}$.

The lower MAT and higher MAP at Longling are the main reasons for the differences in the vegetation at Longling. In the modern vegetation of Yunnan, Eryuan and Yangyi are placed in the same vegetation zone (IIAii-2 domain of semihumid evergreen broad-leaved forest of Hengduan Mountain, western Yunnan), and are even included in the same subdomain (IIAii-2c subdomain of mid-montane Castanopsis delavayi-Lithocarpus forest and Pinus yunnanensis forest of western Yunnan), while Longling lies in another zone (IIAi-1 domain of monsoon evergreen broad-leaved forest and Pinus yunnanensis forest of central and eastern Yunnan) (WGYV, 1987) (Figure 8).

Figure 9 shows the modern hypsographic and climatic change from the Mangshi through Longling, Yangyi (Baoshan), Yongping to Eryuan. It demonstrates that the northwardly moist air-stream may be obstructed by the Gaoligong Mountain causing heavy rainfall and lower temperatures in the Longling area.

Based on the Pliocene climatic data, the MATs are seen to change according to latitude, while the MAP remained roughly the same. It would appear that there was no mountain here at this time. So uplift of Gaoligong Mountain and the eastern portion (Western Yunnan) of the Tibetan Plateau must have occurred during or after the late Pliocene. This corroborates the concept of time-dependent localized shear 


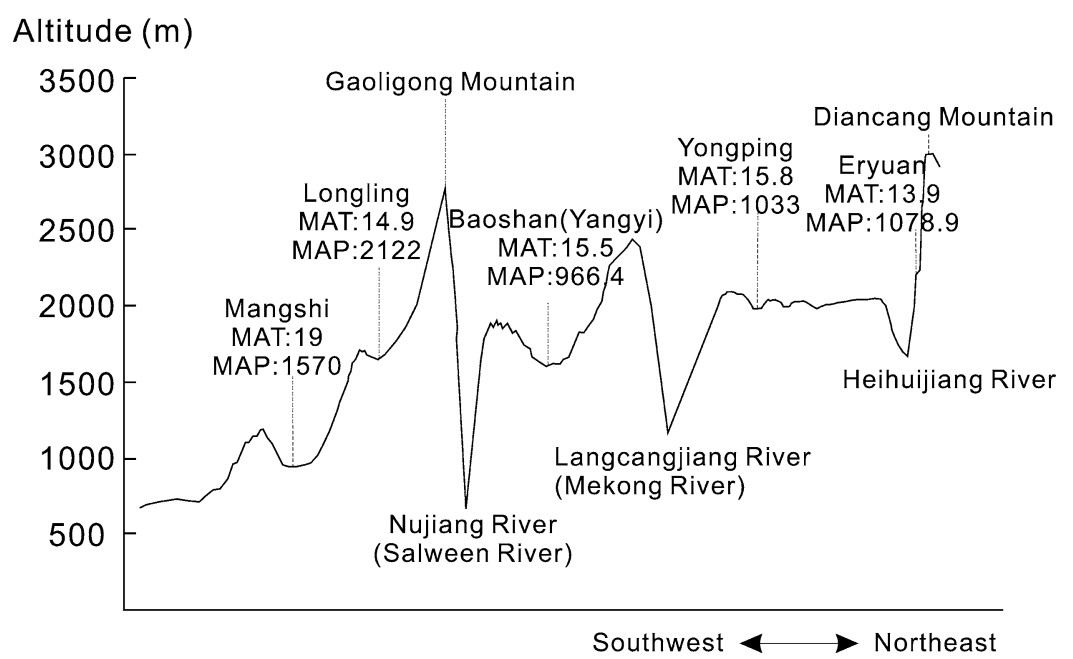

Figure 9. Modern hypsographic and climatic changes form the southwest to northeast in western Yunnan, China. Note: MAT $\left({ }^{\circ} \mathrm{C}\right) \operatorname{MAP}(\mathrm{mm})$.

between coherent lithospheric blocks (Tapponnier et al., 2001), which explains the high elevation of the Tibetan Plateau.

\section{Acknowledgments}

This work was supported by National Basic Research Program of China (2004CB720205), the Key Innovation Project of Chinese Academy of Sciences (KZCX2-SW-118) and by the National Natural Science Foundation of China (40302005, 30470117, 30530050, 40572001).

\section{References}

BGMRYP (Bureau of Geology and Mineral Resources of Yunnan Province): 1990, Regional Geology of Yunnan Province, People's Republic of China Ministry of Geology and Mineral Resources, Geological Memoirs, Series 1, Geological Publishing House, Beijing, pp. 1-728 (in Chinese).

BGMRYP (Bureau of Geology and Mineral Resources of Yunnan Province): 1996, Stratigraphy (lithostratic) of Yunnan Province, Multiple Classification and Correlation of the Stratigraphy of China (53), China University of Geosciences Press, Beijing, pp. 1-366 (in Chinese with English abstract).

Chen, Z. Y. (editor-in-chief): 2001, The Climate of Yunnan, China Meteorological Press, Beijing, pp. 1-196 (in Chinese).

De Buen, L. L. and Ornelas, J. F.: 2002, 'Host Compatibility of the Cloud Forest Mistletoe Psittacanthus schiedeanus (Loranthaceae) in Central Veracruz, Mexico', American Journal of Botany 89(1), 95-102. 
Ge, H. R. and Li, D. Y.: 1999, Cenozoic Coal-bearing Basins and Coal-forming Regularity in West Yunnan, Yunnan Science and Technology Press, Kunming, pp. 1-81 (in Chinese with English abstract).

Hsü, J., Tao, J. R., and Sun, X. J.: 1973, 'The Discovery of a Quercus Semicarpifolia Bed in Mount Shisha Pangma and its Significance in Botany and Geology', Acta Botanica Sinica 15(1), 103-119. (in Chinese with English abstract).

Hutchinson T. F., Boerner, R. E. J., Iverson, L. R., Sutherland S., and Sutherland, E. K.: 1999, 'Landscape Patterns of Understory Composition and Richness across a moisture and Nitrogen Mineralization Gradient in Ohio (U.S.A.) Quercus Forests', Plant Ecology 144, 177-189.

IBCAS and SCIBCAS (Institute of Botany and South China Institute of Botany and Chinese Academy of Sciences): 1982, Angiosperm Pollen Flora of Tropic and Subtropic China, Science Press, Beijing, pp. 1-453 (in Chinese).

IBCAS (Institute of Botany, Chinese Academy of Sciences): 1976, Sporae Pteridophytorum Sinicorum, Science Press, Beijing, pp. 1-414 (in Chinese).

IDBMC (Information Department of Beijing Meteorological Center): 1983a, Land Climate Data of China (1951-1980) (part II), China Meteorological Press, Beijing, pp. 4-5, 72-73 (in Chinese).

IDBMC (Information Department of Beijing Meteorological Center): 1983b, Land Climate Data of China (1951-1980) (part VI), China Meteorological Press, Beijing, pp. 4-6, 126-128 (in Chinese).

IDBMC (Information Department of Beijing Meteorological Center): 1984a, Land Climate Data of China (1951-1980) (part I), China Meteorological Press, Beijing, pp. 4-6, 86-87 (in Chinese).

IDBMC (Information Department of Beijing Meteorological Center): 1984b, Land Climate Data of China (1951-1980) (part III), China Meteorological Press, Beijing, pp. 4-6, 107-109 (in Chinese).

IDBMC (Information Department of Beijing Meteorological Center): 1984c, Land Climate Data of China (1951-1980) (part IV), China Meteorological Press, Beijing, pp. 4-6, 99-101 (in Chinese).

IDBMC (Information Department of Beijing Meteorological Center): 1984d, Land Climate Data of China (1951-1980) (part V), China Meteorological Press, Beijing, pp. 4-6, 108-110 (in Chinese).

Infante, F., Castro, A., Domínguez, E., Guárdia, A., Méndez, J., Sabariego, S. and Vega, A.:1999, ‘A Comparative Study of the Incidence of Cladosporium conidia in the Atmosphere of Five Spanish Cities', Polen 10, 15-23.

Li, X. Q. and Du, N. Q.: 1999, 'The Acid-alkali-free Analysis of Quaternary pollen', Acta Botanica Sinica 41, 782-784 (in Chinese with English abstract).

Maes, E., Iserentant, A., Herbauts, J., and Delvaux, B.: 1999, 'Infuence of the Nature of Clay Minerals on the Fixation of Radiocaesium Traces in an Acid Brown Earth-podzol Weathering Sequence', European Journal of Soil Science 50, 117-125.

Moore, P. D., Webb, J. A., and Collinson, M. E.: 1991, Pollen Analysis, 2nd Edition, Blackwell Scientific Publications, London, pp. 1-191.

Mosbrugger V. and Utescher T.: 1997, 'The Coexistence Approach-a Method for Quantitative Reconstructions of Tertiary Terrestrial Palaeoclimate Data Using Plant Fossils', Palaeogeography Palaeoclimatology Palaeoecology 134, 61-86.

Nardini, A., Salleo, S., LoGullo, M. A. and Pitt, F.: 2000, 'Different responses to drought and freeze stress of Quercus ilex L. growing along a latitudinal gradient', Plant Ecology 148, 139-147.

Tao, J. R. and Kong, Z. C.: 1973, 'The Fossil Florule and Sporo-pollen Assemblage of the Shang-in Coal Series of Erhyuan, Yunnan', Acta Botanica Sinica 15(1), 120-126 (in Chinese with English abstract).

Tapponnier, P., Xu, Z. Q., Roger, F., Meyer, B., Arnaud, N., Wittlinger, G., and Yang, J. S.: 2001, 'Oblique stepwise rise and growth of the tibet plateau', Science 294, 1671-1677.

Vetaas, O. R.: 2000, 'Comparing species temperature response curves: population density versus second-hand data', Journal of Vegetation Science 11, 659-666.

Wang, F. H., Chie, N. F., Zhang, Y. L. and Yang, H. Q.: 1995, Pollen Flora of China, 2nd Edition, Science Press, Beijing, pp. 1-461 (in Chinese). 
WCECA (Writing Committee of Eryuan County Annals): 1996, Eryuan County Annals, Yunnan People's Publishing House, Kunming, pp. 1-769 (In Chinese).

WGYV (Writing Group of Yunnan Vegetation): 1987, Vegetation of Yunnan, Science Press, Beijing, pp. 1-843 (in Chinese).

Wu, Z. Y. and Ding, T. Y.: 1999, Seed Plants of China, Yunnan Science and Technology Press, Kunming (Electronic publication in Chinese).

Xu, J. X., Ferguson, D. K., Li, C. S., Wang, Y. F. and Du, N. Q.: 2004, 'Climatic and ecological implications of late pliocene palynoflora from longling, Yunnan, China', Quaternary International 117, 91-103.

Xu, J. X., Wang, Y. F. and Du, N. Q.: 2003, 'Late pliocene vegetation and paleoclimate of yangyi and longling of West Yunnan province', Journal of Palaeogeography 5(2), 217-223 (in Chinese with English abstract).

Xu, J. X., Wang, Y. F. and Li, C. S.: 2000, 'A method for quantitative reconstruction of tertiary palaeoclimate and environment - coexistence approach', In: Li C. S., (editor in chief), Advances in plant science, vol. 3, China Higher Education Press, Beijing and Springer-Verlag, Heidelberg, pp. 195-203 (in Chinese).

Xu, J. X.: 2002, Palynology, Paleovegetation and Paleoclimate of Neogene, Central-Western Yunnan, China, Ph. D. thesis, Institute of Botany, the Chinese Academy of Sciences, Beijing, China pp. 1-158 (in Chinese with English abstract).

Zhang, R. Z., Zheng, D., Yang, Q. Y. and Liu, Y. H.: 1997, Physical Geography of Hengduan Mountains, Science Press, Beijing, pp. 1-150 (in Chinese with English abstract).

(Received 12 December 2004; Accepted 4 October 2005) 